\title{
Zasa (Weesen) Manor and Park
}

\author{
Jānis Zilgalvis, Dr. arch., a full member of the Latvian Academy of Sciences
}

\begin{abstract}
Zasa manor is located in Selonia and presently it stands out mostly due to its magnificent park which has been created in 18th-19th century and which landscape qualities have not been lost until now. The Greig family played a special role in the culture heritage of the manor. The family lived there for a relatively short period from the middle of the 19th century until the Agrarian Reform of Latvia. It is important to conduct the research of the manor's history and cultural environment since there is little information available. In addition, it is necessary to correct some data and statements that have appeared in the previous publications. There is a necessity to include the manor's park in the national list of protected culture heritage monuments.

Keywords: protection and preservation of architectural and cultural heritage, landscape architecture, protection of cultural and historical environment
\end{abstract}

\section{Introduction}

Very few written records are available about Zasa or Weesen manor both in the 19th century and nowadays. Information about this place is negligible and often similar which could be explained by one source of information which is slightly adjusted from source to source or the same. Zasa manor is mentioned and briefly described in the books of Dainis Bruğis [1], Alberts Zarāns [2], some tourist guides, for example, in the publication of Arvids Plaudis [3], as well as in a brochure in the Estonian language [4]. The author of this article [5] also have described Zasa manor, there are entries about it in encyclopedias [6] and newspaper articles. The last ones are mostly devoted to the park [7], its preservation and current developments in relation to it.

As regards von Sass family, the original owners of the manor, there is no detailed information available about them, but different sources provide varied information about the last owners: they are called Gregh, Greigh, barons Greves, counts of English origin [8], some sources mention their connection with Carskoe Selo management at St. Petersburg, the influence of Gatchina (Гатчино) Gardens in designing Zasa park etc. The aim of the research was to explore the fate of the manors' owners and the property, the design of the park by investigating the available information in literature, internet resources and archives. Initially, it did not produce any results, but then little-known surprising facts were revealed about this remote place of the middle part of Selonia. The article revises and corrects inaccuracies and wrong facts in previous publications.

\section{Owners of the manor in the 18th century and until the 1920s}

In the period from 1644 to 1787 the manor belonged to the von Sass family. In 1680 it belonged to Heinrich von Sass (1636-1706), his wife was Ann Dorothy von Sass, born von Vietinghof-Scheel,

1645-1706), but the first owner was Reinhold von Sass, his father (1602-1648). In 1750 the owner was Gideon von Zass (?-1753), who also owned Scheden manor (the Sass family bought it in 1729). He was the son of Heinrich von Sass. His wife was Margareth Gertrude von Grothuss. There were five sons in the family - Georg, Otto Friedrich, Heinrich, Johann Karl and Reinhold. However, later the owners changed. It is known that on August 25, 1846, Wilhelm von Rummel [9], the former judge of Talsen district and the owner of Sass manor's bonds, passed away (that means that the manor was pledged). Later Wilhelm, allegedly his son, owned the manor; for example, in 1854 and 1861 he allocated funding for reconstruction of Zasa Lutheran church including a new altar piece and pulpit.

In approximately 1865 the pledged manor was bought by Vasily Greig (Грейг). However, before moving on to describing his life and work story, it is necessary to focus on the ancestors of the Greig family. The origins of this family are found in Scotland, in the small port town of Inverkeithing, Fife. The Greigs were not from nobility but their ancestors in the 9th century were related to the king. The family had many descendants forming a kin network in the course of time. The grandfather of Vasily Greigh was widely known and famous Samuel or Samuil Greig (1735-1788), the Russian fleet admiral. In 1764 he as a British naval lieutenant accepted the invitation of the Russian Empress Catherine II (1729-1796) to serve in the Russian navy because he did not see career opportunities in his homeland. He changed his name to Samuil from Samuel. So, he became famous worldwide as Russian fleet admiral due to his superior abilities earning the title of a true member of St. Petersburg Academy of Sciences. He was a military commander, participant of many naval battles, also an expert in shipbuilding and artillery. He took part in formation of Alexander Cannon factory and 
Kronstadt docks, introduced a new signalling system in the fleet, etc. S. Greig was awarded with several orders of the Russian Empire including the Order of St. Andrew, the highest order of chivalry (орден Святого Андрея Первозванного). In 1768 S. Greig married Sarah Cook (1752-1793), a twin sister of James Cook (1728-1779), a famous British explorer. S. Greig died in 1788 during the blockage of the Swedish fleet in the port of Sveaborg. He was buried in the Tallinn Cathedral where the architect of his tomb was G. Quarenghi which was financed by Katherine II. One of S. Greig's son was Alexey Greig (1775-1845), the father of Vasily Greig, who became the owner of Zasa manor. Alexey Greig was a prominent admiral of the Imperial Russian Navy, his godparents were Catherine II and count Alexei Orlov. In 1804 he commanded the Russian Navy in the war against Turkey and France when he was only 30 years old. His career in the navy flourished, and in 1813 he was awarded the rank of vice-admiral and the 1st class of Order of St. Ann (орден Святой Анны первой степени). In 1816 he was appointed the commander of the Black Sea Fleet, a military governor of Nikolayev and Sevastopol. During the Russo-Turkish war in 1828 he was a leader in the attack at the fortress of Anapa. He was awarded the rank of admiral after the victories. A. Greig was a man of various interests and knowledge. He knew several languages, painted, took interest in different scientific areas, later he was appointed an honorary member of the Academy of Sciences. In addition, A. Greig dealt with horticulture, plant acclimatization etc. He was elected a member of the Moscow Society of Naturalists. This fact could explain a myth that Greig, an owner of the Zasa manor, had been a manager of Carskoe Selo (Царское село) and many of design ideas from there implemented in Zasa manor [10]. When Greig became an owner of Zasa property, his father had died some years ago. As regards the position of a manager at Carskoe Selo, the analysis of the Carskoe Selo register of persons from 1710 to 2010 did not reveal any person with such a surname [11]. On the other hand, Vasily Greig had a brother, Samuil Greig, a Russian army general and a minister of finances (1878-1880), who was indirectly related to the park designing culture. In 1870 he proposed to establish Admiralty Park in St. Petesburg to commemorate 200 years of Emperor Peter I (16721725). He was also a president of Russian Emperor's Horticultural Society (Императорское Россйское общество садоводства) [12]. This fact could be the reason why someone without proper knowledge could mention Carskoe Selo in connection with Zasa manor [13].

The personal life of the father of Zasa manor's owner is interesting and unusual. When he was 46, he fell in love with and married Yulia Stalinska
(Rafalovich) (1800-1881) which was of Jewish origin. Intrigues, complaints and lies did not allow this marriage to be publicly recognized. It happened only a little later when their children came to the world and one of them was Vasily Greig, an owner of Sass property. He was born in the city of Nikolaev in Kherson region in 1832 and spent his childhood with his brothers and sisters in St. Petersburg. In 1850 he joined the military service, then took part in the Crimean War. From 1869, V. Greig served as the chairman of the Vidzeme Control Chamber, in 1873 he was promoted to the rank of the colonel, but soon after moving to the civilian office he became a councilor of the court and headed the State Chancellery in St. Petersburg. In 1877 he was assigned a true state counselor that was equal to the rank of general in the military service. After two years, V. Greig was awarded the title of the court's chamberlain of the emperor's palace. In 1885 he became also a member of the Council of the Ministry of Finance. It is hard to say why his choice fell directly on Zasa property, a remote corner of Selia. One of the reasons could be that it was a good offer or he noticed the property, and he liked the place while he was working in Vidzeme Control Chamber. In 1859 V. Greig married Maria Kuming (1837-?), they had four children: two daughters, Vera (1862-1843), Countess Tolstoy after the marriage, and Helen (1871-?), as well as two sons, Alexis (1859 - after 1912) and Samuil (1872-?) [14]. Vasily Greig died in 1902. The manor was inherited by his son Alexis who was mentioned as the last owner in the documents of the agrarian reform with the note that the inalienable possession of the estate's centre now belonged to Nikolay Greig [15], the son of Alexis. Alexis Greig, a headmaster of headquarters, was mentioned in the Richter Address Book as the manor's owner [16]. It is stated in the book that since 1904 he lived in the manor. Its manager was baron N. Hahn.

The life of the Greig family was also witnessed by the chapel located in Zasa church yard opposite the main entrance. It was rectangular, with a semicircular apse. Arvids Gusars, a fellow member of the Board of Monuments, informed the board in 1928: 'when I arrived at Zasa near the church, I found only the foundations of the former chapel. Chapel was demolished 3 years ago by the local manor owner Greig, who was given a chapel along with the manor. The chapel had been built in a Greek style, its facade had been decorated with four marble columns with figurine angels at the top. The building itself had been made up of red bricks. Now one can see a ruined cellar through brick debris' [17]. Currently nothing has been left from the building only the traces of the former foundations in the earth. 


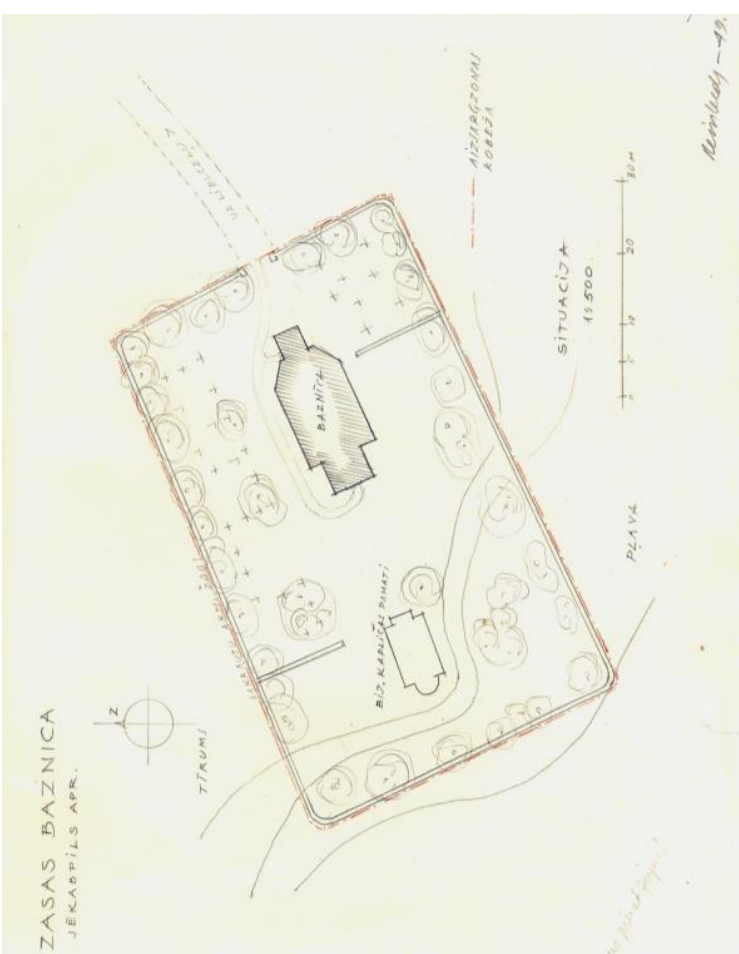

Fig. 1. The layout plan of the Zasa lutheran church and a chapel [State Inspection for Heritage Protection of the Republic of Latvia, Monument Documentation Center, 1928]

The largest part of the land of the manor's estate was divided into 88 newly establish farms during the agrarian reform. Certain areas were left and adjusted for public needs, for example, the parish house, the church, the cemetery, the house for people in need, the brick factory, the parish school etc [18]. The inalienable possession, including watermill, was left to the former owner of the manor. In 1921 it is stated that 'all buildings of the manor are old except cattle shed which also cannot be used otherwise than transferring it to the former owner; other buildings located in the center of the manor have been taken by the parish community' [19].

In 1924 the centre of the manor along with the water and steam mill was purchased by Indrikis Stukulis from Nikolai Greig, the owner of the manor. Stukuls' skillful management of his new property produced remarkable results. After his death, the property was inherited by his son, Vilis Stukuls (1909 - 1996), a prominent horse breeding specialist who was an owner of Zasa in the 1930s. The property was renamed Berrzemnieki to honour the memory of his father, which was the former surname of this family. Famous people of that time enjoyed Zasa hospitality. One of them was Jānis Jaunsudrabiņš, a famous Latvian writer and artist. V. Stukuls wrote in his memoirs about him: ... The day was devoted to walks and painting in Zasa Park. The park provides opportunities not only for relaxation, but also for painting and fishing [20]. V. Stukuls' property was nationalized after 1940, however, when the independence of Latvia was restored, the manor was returned to his heirs, but then it was sold to a private individual.

\section{Manor's buildings}

Unfortunately, there is no information about the estate's buildings in the 19th century. However, in 1921 the inventory list of the buildings [21] made up by J. Klaviņš, a surveyor, registered the following buildings in the territory of the estate; they are numbered in the successive order:

1. a shed with brick poles, shingled roof;

2. a building for drying crop made of boulders, shingled roof in good condition;

2. a an attached building to the barn;

3. a building for drying crop with stone and wooden window;

4. a grain drying building made of boulders covered with shingled roof which has decayed;

5. a dwelling house made of boulders roof insulation is made of cardboard;

6. a school, brick masonry, roof shingles in a bad condition, the school has the second floor;

7. a dwelling house made of stones covered with shingled roof, which is old;

8. a barn made of wood, stone poles, shindlesd roof, old;

9. a horse stable, boulder masonry, shingled roof in good condition;

9.a a horse stable;

9.b a horse stable;

9.c a horse stable;

10. a barn, boulder masonry, shingled roof in good condition;

11. a dwelling house (a castle), wooden, shingled and cardboard roof, the roof has decayed;

11. an attachment to the house;

12. a dwelling house made of bricks, shingled roof;

13. former greenhouse made of bricks, shingled roof, old;

14. a dwelling house made of bricks, shingled roof, two-storied;

15. a horse stable made of bricks, shingled roof, new;

15. an attached building;

16. a barn with brick poles with boards, an old roof, there is a cellar;

17. a dwelling masonry house, shingled roof;

18. former poultry house made of logs with shingled roof, the roof and walls have decayed;

19. a toilet made of boulders with shingled roof;

20. a dwelling house made of logs with shingled roof; the roof and walls have decayed;

21. a barn, with log and stone poles;

22. a dwelling house made of bricks, tile roof;

23. a pub made of stones with shingled roof;

24. a barn made of logs, decayed;

25. former warehouse made of boulders, tile roof, old. 
Not much from the list have been maintained till the present day. The buildings mostly were covered with shingled roofs, only two of them had tile roofs, many barns built in a characteristic manner by installing logs or boards between masonry posts, two from buildings were log cabins but they were in bad condition. Unfortunately, the land plan related to the inventory list was not found in the mentioned archive documents even though the numbers show that there has been one.

Today the building of the rest of the estate center is grouped around a rectangular courtyard, the shape of which is still visible. Only ruins have survived from the masters' old houses - a piece of boulder wall with two symmetrical round window shapes. In the second part of the 19th century a new masters' house was built, but it was burnt down in 1905 . This small building remotely reminded the cottage or the country house in Peterhof [22] built for Russian Emperor Nikolas I by A. Menelas, Menelaws, 1747-1831, an architect of Scottish origin. It was located in Alexandria, in the Emperor's sea coast residence, on the eastern border of Peterhof Low Park. The cottage was built and decorated between 1826 and 1829 in romantic Gothic shapes. In the architecture of Zasa summer cottage (the second half of the $19^{\text {th }}$ century) Gothic shapes dominated, but with the characteristic interpretation in wooden construction techniques, both by means of architectural and decorative solutions - in the window openings, decorations of stair railings, roof gables and elsewhere. The photo of this unusual house was published at the beginning of the $20^{\text {th }}$ century by Dainis Brugis [23] and this is the only known information about this building. A summer residence was suitable for the Greig family because they stayed in Zasa only in a warm season, but winters were spent in Petersburg. The colour of the paint of the house could be chosen to resemble the fashion in the court. The two-storied wooden building had a porch, bay windows; the facades were pompously decorated. We do not know anything about the interior of the manor house. There is only one chair that came from Zasa manor; since 1959 it is in stock of Kruspils castle (Jekabpils History museum). It is known that for some time it was situated in the altar part of Zasa lutheran church [24]. The chair was made in early Renaissance style known as board chairs or Dantes' chairs due to the fact that two flat boards were used instead of legs, one of which extended the backrest.

The ruins of the oldest masters' house reveal a small wooden building on the right, where the post-office was situated already during the agrarian reform. It was built as the Greig's summer cottage after the burning of the previous house. The construction design is simple and traditional to fit in the building planning of a rural town. The side

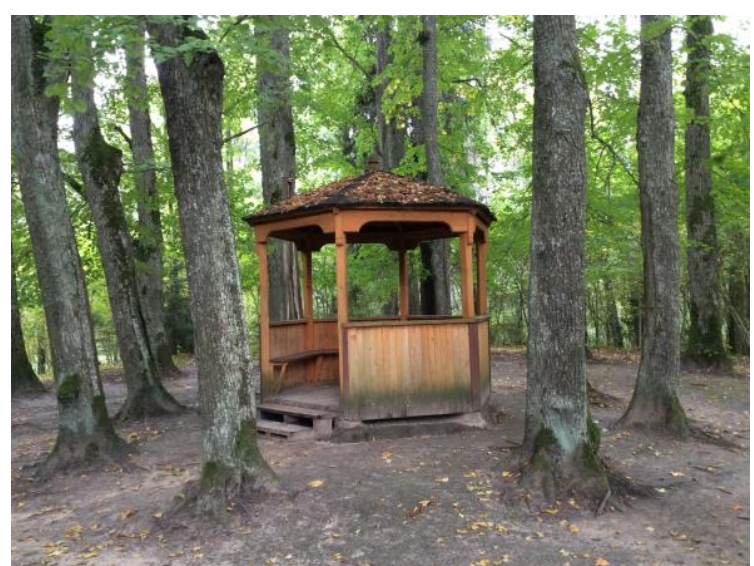

Fig. 2. An arbour on the co-called Cukurkalniņš (Sugar hill) [photo by the author, 2017]

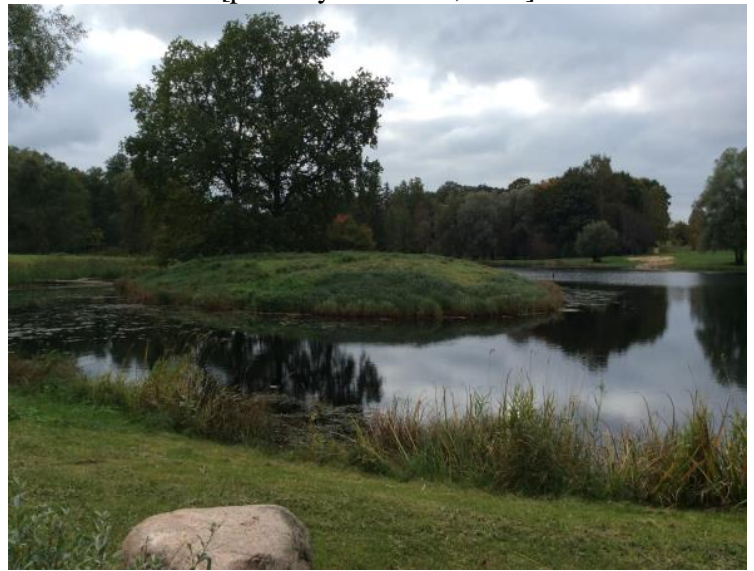

Fig. 3. The view on the Zasa park from the watermill [photo by the author, 2017]

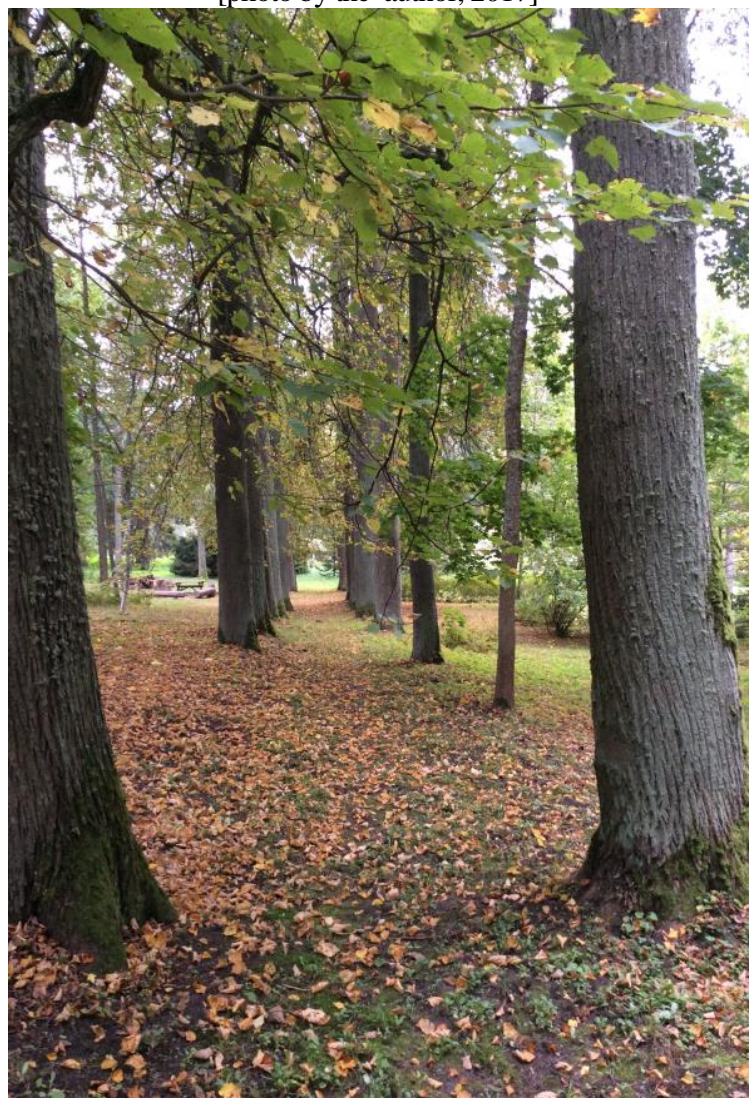

Fig. 4. One of the ancient alleys of the park created during the time of the Sass family [photo by the author, 2017] 
of the yard is occupied by a two-storied building, a former granary. The second floor was added in the 1920 s for the needs of a veterinary office. There are vaulted cellars under the building. There was a laundry once in close distance from this buiding, but its foundations were used to build a new dweling house. The foundations made of boulder masonry are apparent even now. Next to them one can see the remains of another rectangular building the purpose of which is not clear. It is worthwhile to note that it has double cellar walls - approximately one metre distance from each other. The other side of the road leading to the yard is marked by the big enclosure with the boulder masonry building built in the $2^{\text {nd }}$ half of the $19^{\text {th }}$ century with a partly closed yard. One side of it is occupied by a large barn made of boards attached to the building. The estate contains also the former brewery which later served as the house for servants. The two-storied building of the $19^{\text {th }}$ century has a two-sloped roof with semisharpened edges and a cornice with fine shaping. Outside door leaf construction of the servants' house has interesting features (the last quarter of the $19^{\text {th }}$ century). It has paneling construction. Paneling has a double frame, the bottom side is slightly folded, but in its middle there is a circular belt with a roze decoration in the centre. The luxurious door would be hardly meant for the servants' lodgings, most probably it was made for the brewery which had been in this building previously. Other buildings, their remains to be more exact, of the estate are grouped around the brewery (the servants' house). The ruins of the cattle shed, the foundations of some farm building and a cellar cottage belong to them.

The farm buildings include also the mill (19 $9^{\text {th }}$ century) which, as it was mentioned before, was purchased by Indrikis Stukuls in the middle of the 1920s. In 1927 he wrote the following in the application for the adjustments of the mill's land management project: “...my mill consists of four passages, cylinders, wool processing devices, saw mill, planing workshops etc. with $132 \mathrm{HP}$ ',[25]. It seems to be a production unit. The mill is located near the road and it consists of several related volumes. There is a high red brick tower on one side of it. A historic equipment has bee maintained in the mill. A fragment of the mill stone is installed in the the building's façade facing the road with the year of building and the initials of the builder W.v.G. 1887 engraved on it. Currently a hostel is operating in one part of the mill. On the opposite side of the road there is a miller's house which was built in the middle of the $19^{\text {th }}$ century. This building has been reconstructed in the first decade of this century - there is a living space in the roof with a balcony which does harmonize with its historic image.

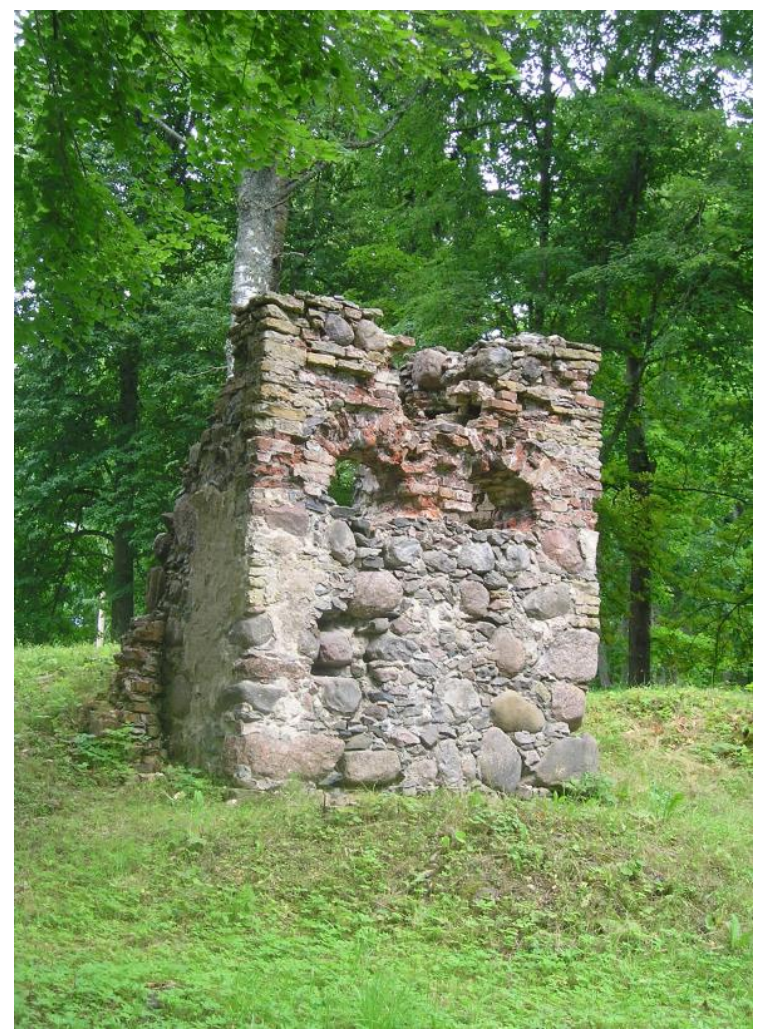

Fig. 5. The remains of the masters' house [photo by the author, 2017]

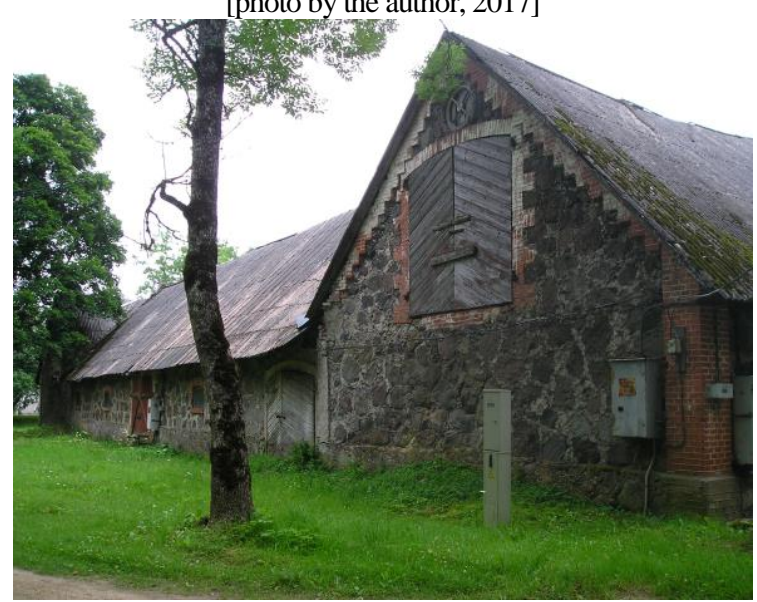

Fig. 6. Enclosure [photo by the author, 2017]

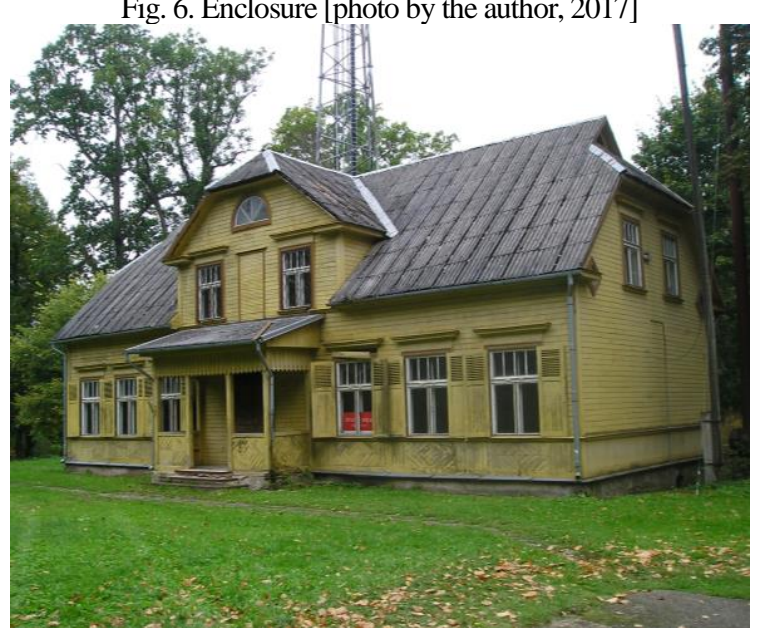

Fig. 7. The summer house, later used as a post-office [photo by the author, 2017] 


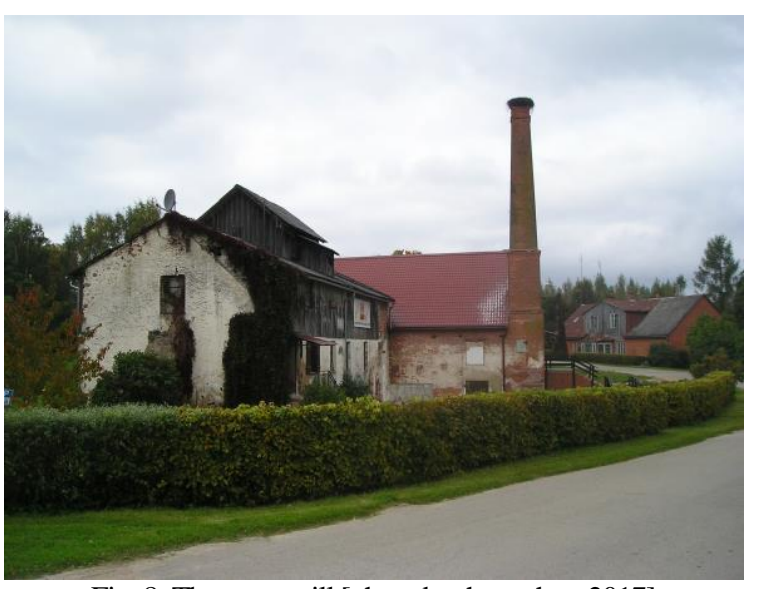

Fig. 8. The watermill [photo by the author, 2017]

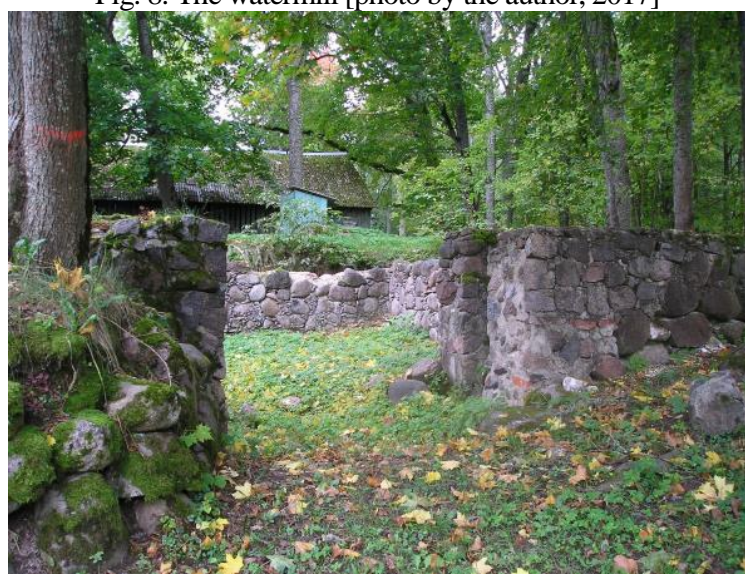

Fig. 9. A farm house with double walls in the cellar [photo by the author, 2017]

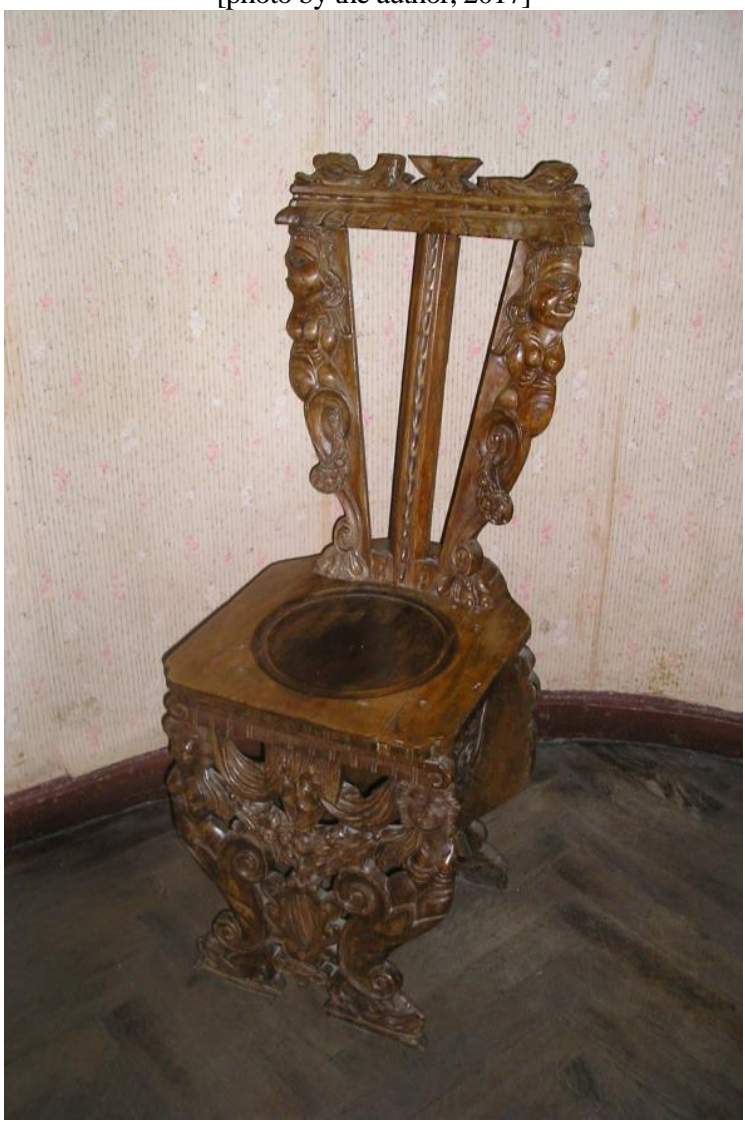

Fig. 10. The chair from Zasa manor, now an exhibit of the Krustpils castle [photo by the author, 2017]

\section{Parks}

The park of Zasa manor is one of the most beautiful, cultivated and lovely places in Selonia. It is about 23 hectares large and its designing began already in the $18^{\text {th }}$ century by Baron von Sass, and it has features of a romantic landscape park. It is often mentioned in various publications that it reminds Gatchina Park of St. Petersburg regarding its composition and structural design. This park is composed of several parts and it has been created gradually from 1766 to 1783 (architect A. Rinaldi) and at the end of the $18^{\text {th }}$ century by architect N. Lvov (Львов). Probably the similarity is seen in the main park, the so-called Castle Park, which combines large lakes with picturesque islands and a lot of small architectural forms. The main motif of the composition here is water. The lakes are located not at the edges of the park, but in the center of it and it is the dominating feature. The surface of the water is seen from a distant view, small bays and streams attract attention from close proximity. In addition, the water surface reflecting plants of a variety of colour shades not only makes the landscape attractive, but also intensifies the impression of a painting and comprehensive space. The surface of the water reflects the sky and the sky itself creates a mysterious depth effect. All of the above mentioned can be referred to Zasa Park. Certain merits of the development and cultivation of this park could be attributed to the Greig family members, in particular to Vasily Greig.

The oldest, currently known information about the design of the park associated with the ponds refers to two land plans from 1924 and 1928 [26]. The configuration of these ponds has not changed significantly to this day. There have been three bridges in the narrow places of the water bodies. It is interesting that at the highway leading to the centre of Zasa on the side of the park in 1928 the water level was raised. In 1967, Latvia's topographical plan showed only few flows, but nowadays this area again has a large water surface. Groups of trees are visible in the distance over it. This water surface with reflections informs us about the expected beauty created by the nature and human hands here.

The park is decorated with several flushed ponds which are connected through the river Zasa which in the park's territory has the name of Dzirnupite. The ponds include the buildings of the estate's centre in the semi-circle. The ponds have acquired names over the time - Yellow, White and Pink Pond. Four bridges are created at the connection points of ponds. In all seasons there are picturesque views on the centre of the estate, the nearby church and the mill. There are several islands in the ponds, and one of them is named Love Island; the name is associated with unhappy love of a local gardener and the owner's daughter of the manor. There is also 


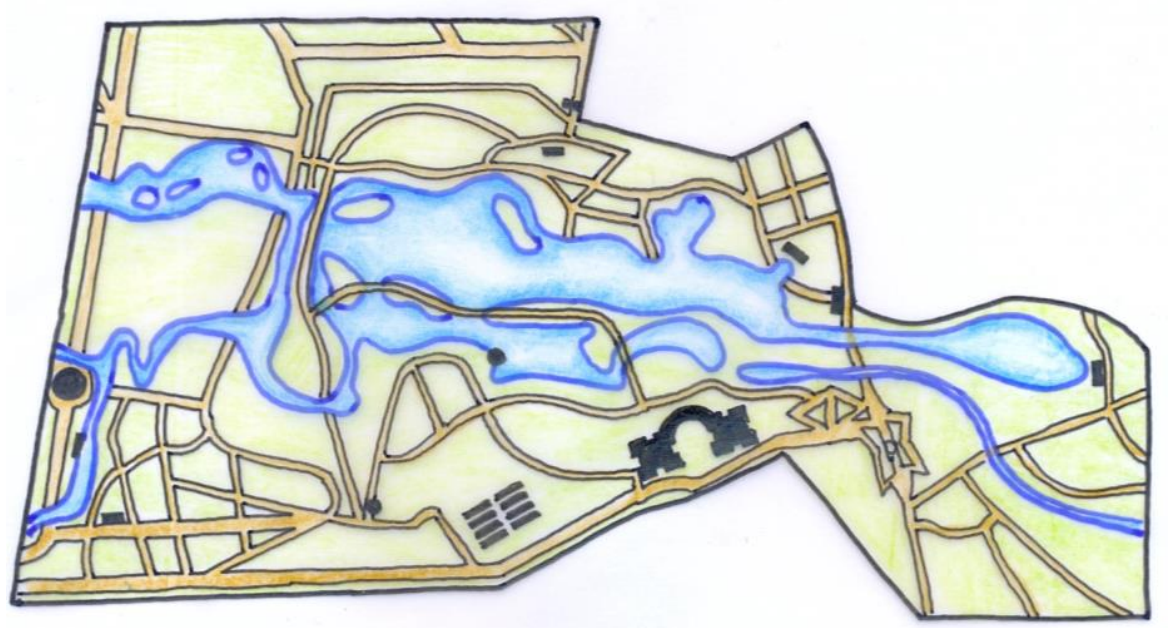

Fig. 11. The landscape design of Gatchina Park [created by the author]

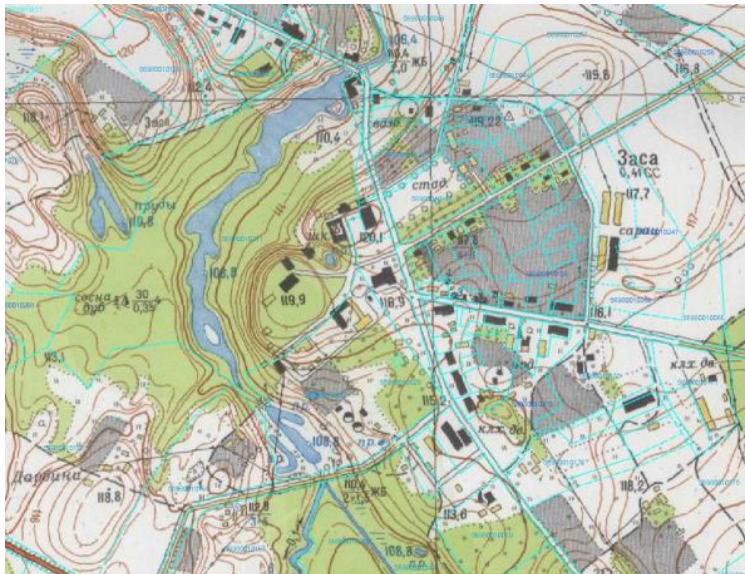

Fig. 12. Topographical plan of Latvia in 1967. An extract. [Latvia State Inspection for Heritage Protection. Monuments Documentation Centre]

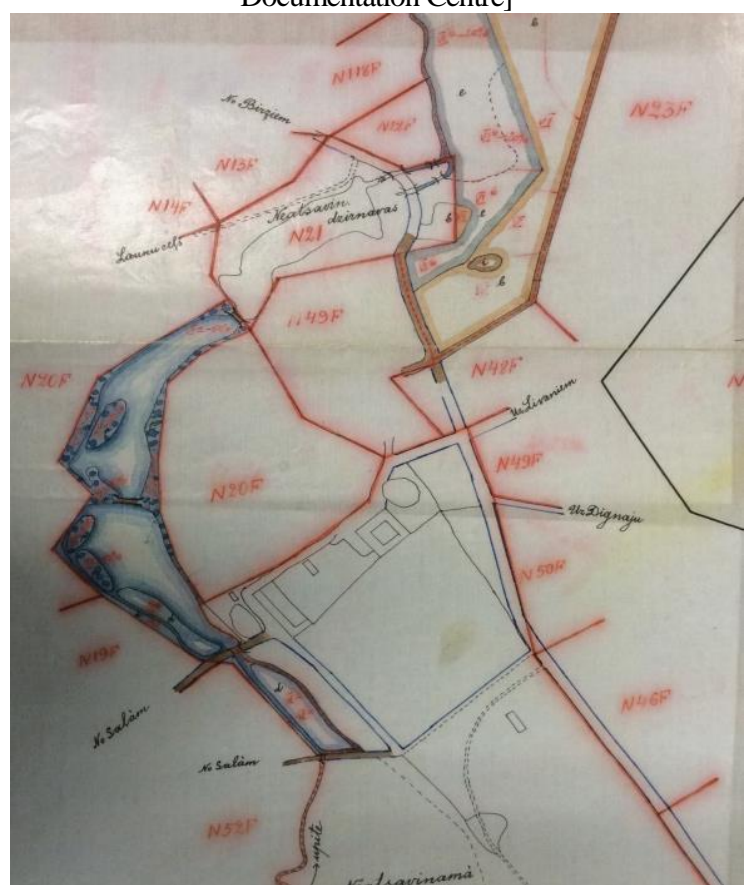

Fig. 13. Division of Zasa estate's farms and the plan of changes in the design. An extract. 1928

[Latvia State Historical Archive, 1679, f., descr. 172., p. 543.]

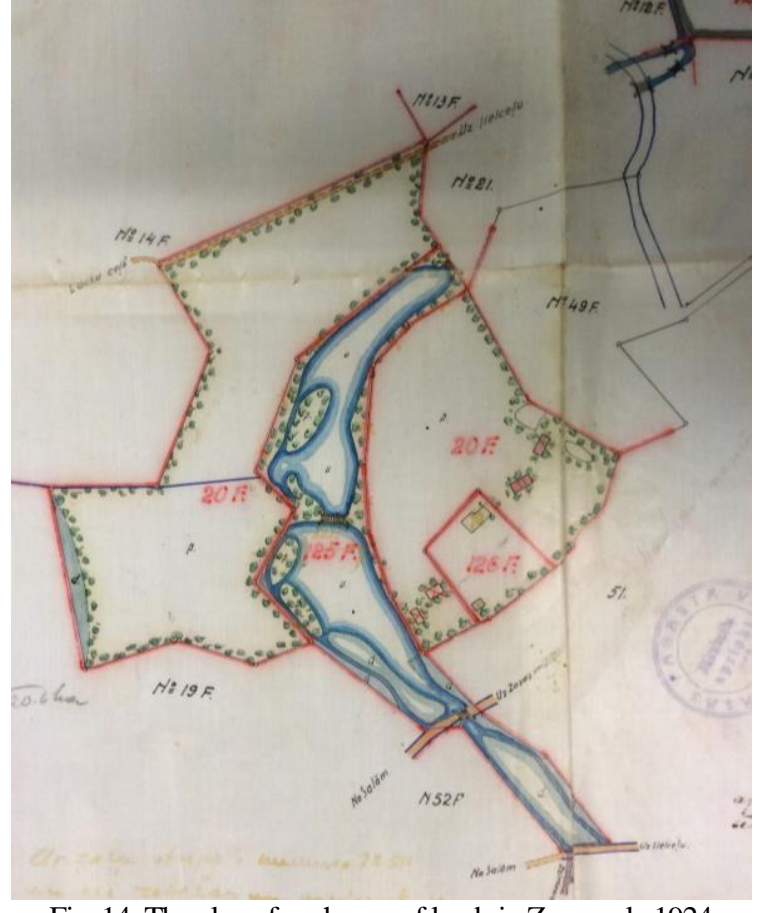

Fig. 14. The plan of exchange of lands in Zasa park. 1924 [Latvia State Historical Archive, 1679., f., descr. 172., p. 543]

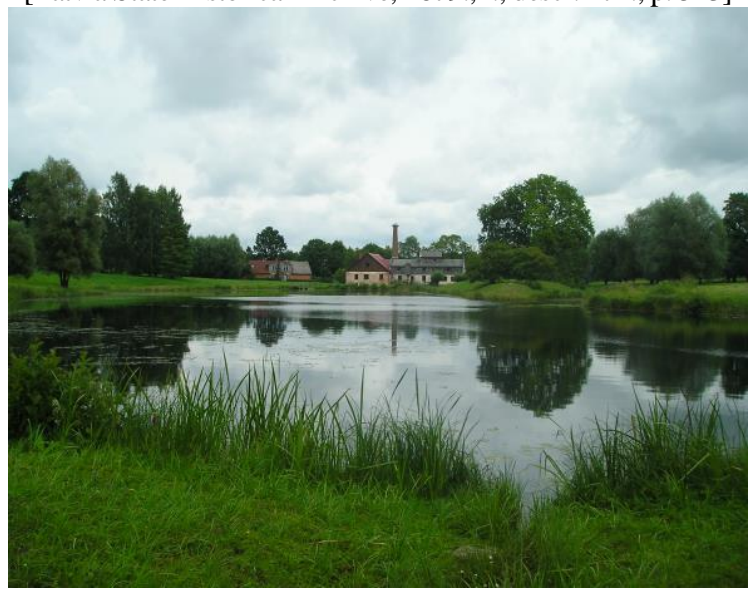

Fig. 15. Park with the watermill [photo by the author, 2017] 


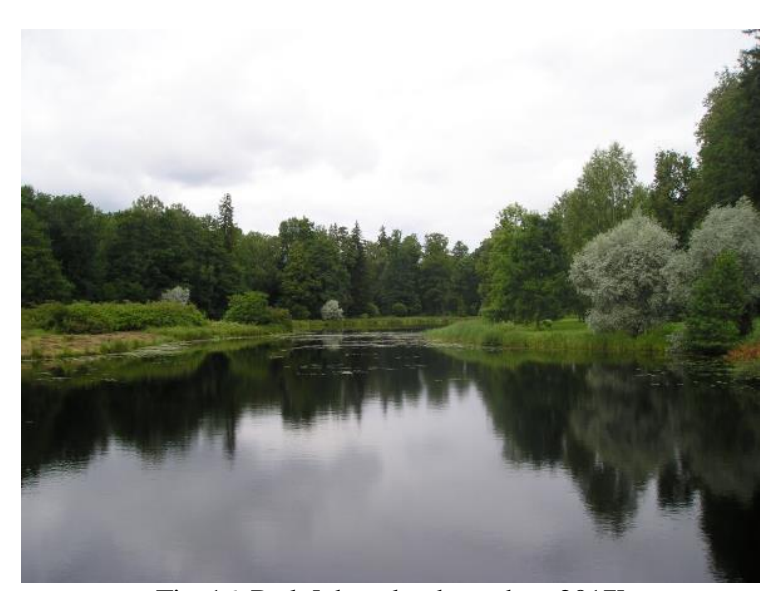

Fig. 16. Park [photo by the author, 2017]

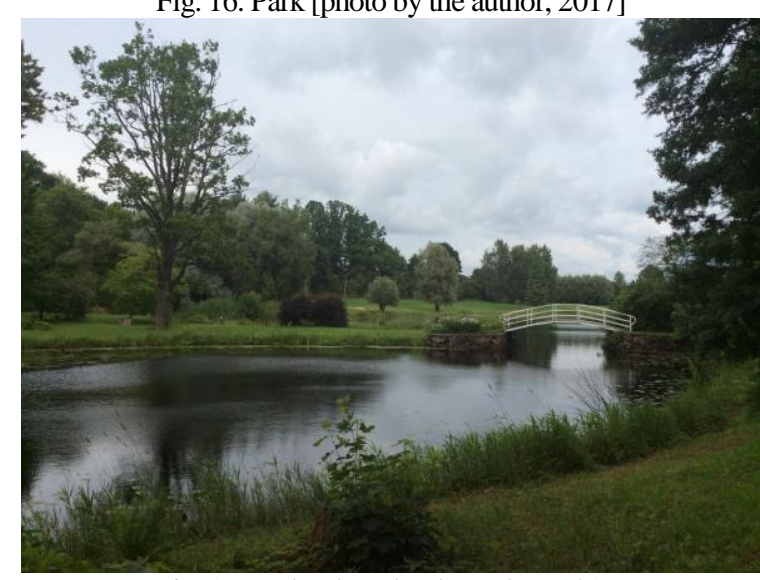

Fig. 17. Park [photo by the author, 2017]

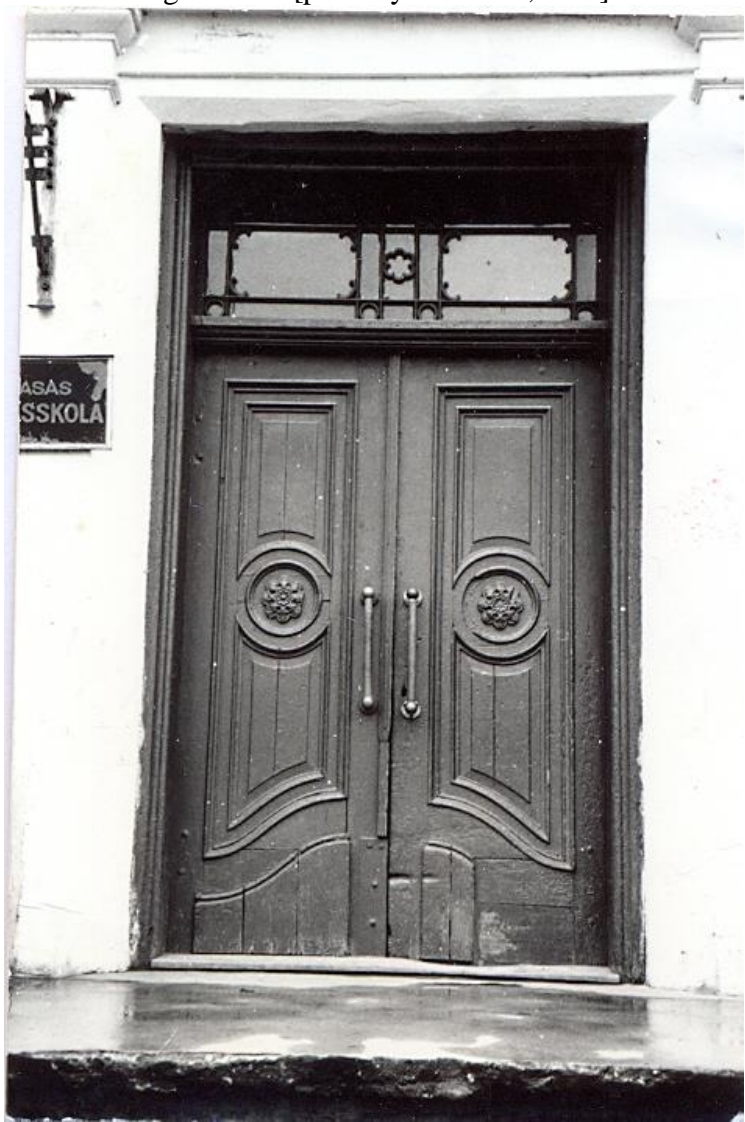

Fig. 18. The main entrance into the secondary school of Zasa [photo by the author,1998]

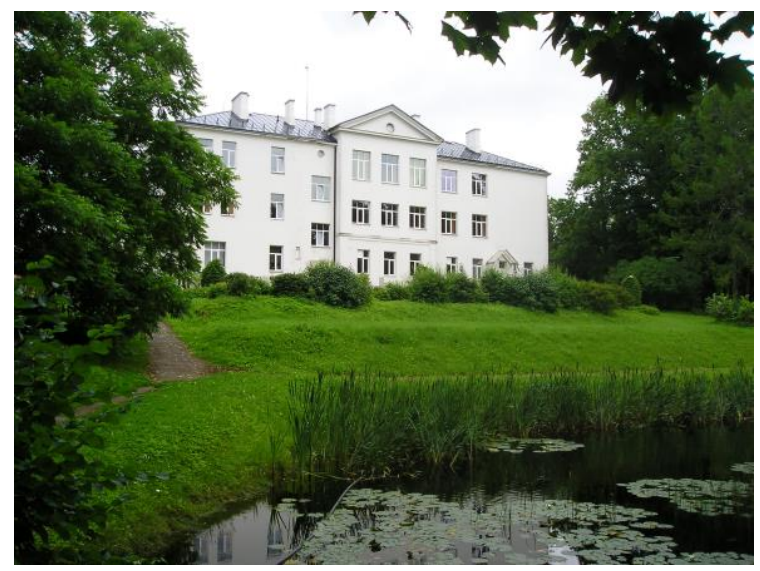

Fig. 19. Secondary school of Zasa [photo by the author, 2017] a divine spring, which was once a worship place of Selonians. There is also a small pond opposite the school. It has a fountain, water lilies, a foliage of trees falls over the pond from one side, the other view is more panoramic. Next to this pond there is another, smaller pond of a rectangular shape.

Vast water bodies creating the pond system play an important role in the atrractiveness of the park. In some places plants occupy areas close to the shore and various coulours are reflected in the water surface. Plants elsewhere are in far distance behind the meadows. The water surface reflects the sky here and individual trees creating the foreground of the distant landscape.

Trees and shrubs are chosen in a variety of colours from dark blue green to silver velvet. They make up both impressively pronounced and gentle water flowing play of shadow and light. The park is also a place of various emotions. Moving across the bridges one has the feeling that lovers meet here frequently and are inspired by the beauty of the surrounding nature. A completely different type of emotions appears on the boat rowing through the park's ponds. Each moment a new view appears with a hidden secret or surprise behind each turn, and one wants to believe that the life also will be interrupted with something new and unexpected.

A particular attention is paid to the species of trees and shrubs from abroad. There are white fir trees, silver willows, black and Weimouth pines, Tunberger's barberry, Cornus Alba plants, and others. As regards caulescent plants, there are mainly moisture-loving species: Sahalin's hydropipers, large bearded bellflowers, low myrtles and others. Besides the ruins of the former old masters' house, on the edge of the pond there is a terrace for rest arranged in the Soviet time with a small pool and a fountain which has not worked for a long time. A little hill on the edge of the pond just opposite one of the islands, the so-called Sugar Hill, is surrounded by centuries-old trees. The stories are told that the owners of the manor used to have coffee without sugar on weekdays and coffe with 


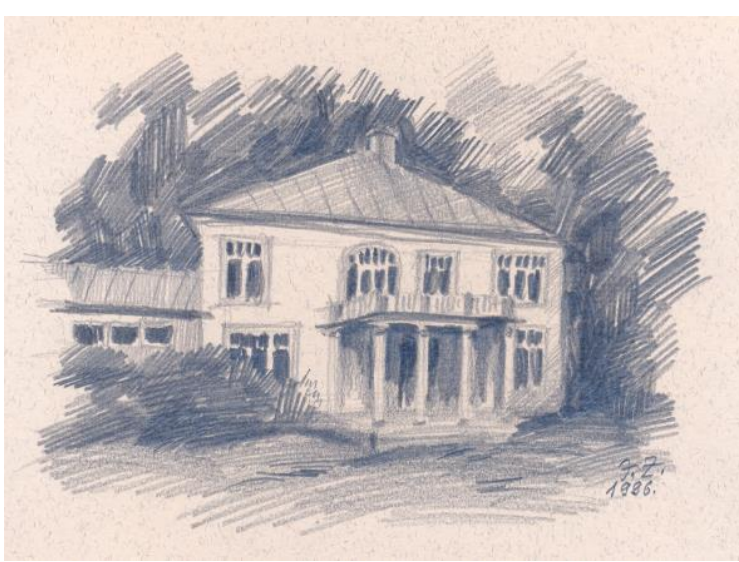

Fig. 20. Stukuls mansion [drawing by the author, 1996]

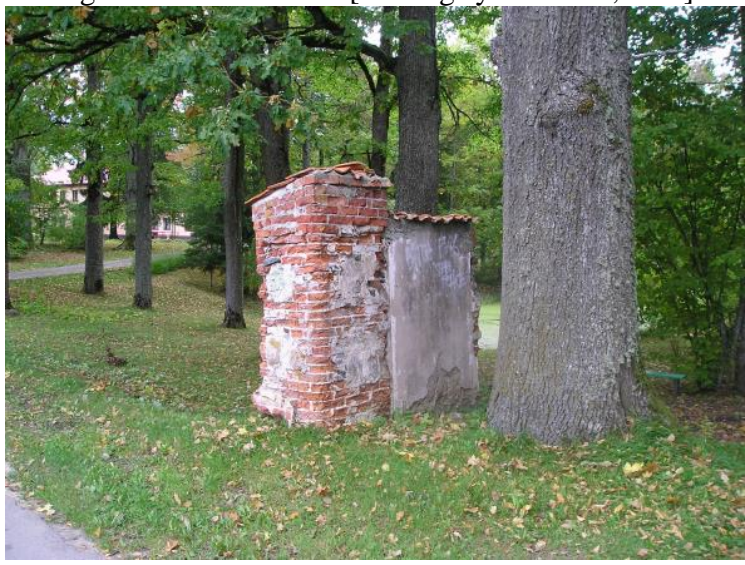

Fig. 21. The fragment of gates from Zasa manor in the park [photo by the author, 2017]

sugar on Sundays. There has been an arbour on the hill. It has been repeatedly restored over time, however, it was burned down in 2007. Two 200year-old linden trees were damaged during the incident. Later the arbour was restored in the shape of a traditional park design and has survived to this day. It has polygonal shape with benches inside and decorative supports. Zasa Park is the place where one would like to come back again and again enjoying its radiant peace and thinking about eternity - and that's just love ...

The old park has had its own continuation in the recent past. On the birthday of V. Stukuls in 1927 , the guests planted a birch grove. Now it is called the Stukuls Grove and the birches are still green. The grove is situated opposite the former Zasa collective farm's petrol station.

Inside the park there is the secondary school of Zasa (1939), which previously had the same outside door leaf construction as the brewery, but now it is replaced by the new impersonal door. Behind the boulder masonry fence the so-called
Stukuls Mansion (the 1930s) is hidden. Its main façade is facing the exit from the park. The building is characterized by the manifestation of the greatness of a wealthy host of his time. It is interesting to note that the Stukuls family photo was placed on the cover of the famous journal "Atpūta" in 1932. Zasa Park was considered to be of a special value in the 1930s and was named as a park to be preserved in many agrarian reform documents. For example, in 1940 the report of the project for the division of protected Zasa Park stated that there was no agreement received to remove the Zasa mill river as a separate object from the park's area [27].

Zasa Park undoubtedly requires further detailed research. However, it can already be argued that this is one of the most historically significant examples of manor landscape parks in Latvia, and it has a remarkable landscape and dendrological quality.

\section{Conclusions}

The last owners of Zasa estate up to the agrarian reform of Latvia were the Greig family representatives. It was bought in the 1860 s by Vasily Greig, whose grandfather and father were admirals of the Russian Navy, well-known personalities. No substantial information about this family has been published in Latvia until now. Some minor articles have mistakes and inaccuracies that are now being corrected. The fate of Zasa manor after the agrarian reform of Latvia is associated with the Stukuls family, who were prominent farmers; their representative Vilis Stukuls was a well-known horse breeder. Stukuls Mansion today expresses architectural manifestations of the 1930s in the design of the central part of manor's estate. The school building of Zasa is a significant example of the building art of the time of the independent Latvian state.

Zasa manor park, as evidenced by the field research, the identification and analysis of literature and archive materials, is one of the most important culture heritage landscape parks in Latvia. It has excellent scenic and dendrological quality. The park has, on the whole, retained its design and spatial structure to this day. The above said allows to make a conclusion that it is necessary to propose the inclusion of Zasa manor park in the List of State Protected Cultural Monuments as a national monument.

\section{References}

1. Brugisis, D. Historisma pilis Latvijā. Rīga: Sorosa fonds Latvija, 1996, 138., 139., 196. lpp.

2. Zarāns, A. Neesam šķirami no savas zemes. Rīga: Zelta grauds, 2003, 157. lpp.

3. Plaudis, A. Cel̦edis pa Latviju. Rīga: Jumava, 2000, 213., 214. lpp.

4. Sakk, I. Läti mõisad. Reisijuht. Tallin: Sakk, 2006, 261. lpp.

5. Zilgalvis, J. Daugavas muižas. 18. gs. - 20. gs. sākums. Rīga: Izglīīība, 1998, 109., 110. lpp., Zilgalvis, J. Daugavas muižas. 18. gs. - 20. gs. sākums. Atkārtots un papildināts izdevums. Rīga: Izglīîiba, 2002, 129., 130. lpp., Zilgalvis, 
J., Muceniece, A. Vēsturiskie dārzi un parki. Eiropas kultūras mantojuma dienas 2007. Rīga: VKPAI, 2007, 62. lpp. u. c.

6. Enciklopēdija Latvijas pagasti. Latvijas pagasti, novadi, pilsētu un novadu lauku teritorijas. Rīga: A/S Preses nams, 2002, 2. dala, 659. - 661. lpp.

7. Diopa, D. Kultūrkapitāla fonds atbalsta Zasas parku. Brīvā Daugava [Jēkabpils], 2008, Nr. 114. Mikanovska, S. Vandąii sadedzina 200 gadus vecas liepas. Jaunais vēstnesis [Jēkabpils raj.], 2007. gada 27. aprīlis., Lielmeža, B. Zasas parks. Brīvā Latvija, 2003, Nr. 33., Rupenheite, I. Zasas lauki. Kur slēpjas zelta kariete un spēkavots. Diena, 1998. gada 7. augusts.

8. Zasas muiža. [tiešsaite] Vietas: Latvijas cel̦edis [skatīts 06.08.2017]. http://www.vietas.lv/objekts/zasas_muiza/

9. Das Inland. Eine Wochenschrift für Liv-, Esth- und Kurlands Geschichte, Geographie, Statistik und Literatur. Dorpat: Heinrich Haakmann, 1846, S. 908.

10. Zasas muiža. [tiešsaite] Vietas: Latvijas celvedis [skatīts 06.08.2017]. http://www.vietas.lv/objekts/zasas_muiza/

11. Управление, охрана порядка, социальные службы в Царском Селе. [unline] Энииклопедия Царского Села [cited 04.08.2017]. http://tsarselo.ru/yenciklopedija-carskogo-sela/upravlenie-ohrana-porjadka-socialnye-sluzhby-vcarskom-sele/

12. Сады и парки Санкт-Петербурга 19 - начало 20 века. Сост. Н. Г. Жукова. Москва, Санкт-Петербург: Центрполиграф МиМ-Дельта, 2004, стр. 70.

13. It is interesting to note that in 1884 the Riga Garden Architect G. Kufalt, who advised the creation of many manor parks in Latvia, Estonia and russia, participated in the International exhibition organized by the Russian Society of Tea and Wildlife. See more: Kāvere, A. Rīgas dārzu arhitekts Georgs Küfalts. Rīga: Jumava, 2007, 73. lpp.

14. http://ru.rodovid.org/wk/ Skatīts 06.08.2017.

15. Latvijas Valsts vēstures arhīvs (LVVA) F. 1679., descr. 172., p. 543.

16. Richter, A. Baltische Verkehrs und Adressbücher. Riga: Im Selbstverlage des Herausgebers Adolf Richter, 1912, Bd. 2., Kurland., S. 631.

17. Valsts kultūras pieminekḷu aizsardzības inspekcijas Pieminekḷu dokumentācijas centrs (VKPAI), lieta Zasas luterāṇu baznīcas kapliča.

18. LVVA F. 1679., descr. 172., p. 543.

19. LVVA F. 1679., descr. 172., p. 543.

20. Stukuls, V. Krustpilieša stāstījums par dzimto novadu, saviem priekštečiem un dzīves gaitu. Madona, 1992, 91. lpp.

21. LVVA F. 1679., descr. 172., p. 543.

22. Bruğis, D. Historisma pilis Latvijā. Rīga, 1996, 138., 139. lpp.

23. Brugisis, D., ibid, 139. lpp.

24. Mašnovskis, V. Latvijas luterāṇu baznīcas. Vēsture, arhitektūra, māksla un memoriālā kultūra. Rīga: Due, $2007,4$. sēj., 423. lpp.

25. LVVA F. 1679., descr. 172., p. 543..

26. Zasas muižas neatsavināmās daḷas un muižas valsts fonda zemes - rezervētās pie neatsavināmās Zasas muižas üdensdzirnavu un atseviški izdalītās daḷas apmaiṇas projekta plāns. 1924., vecākais mērnieks J. Jansons un Zasas muižas saimniecību sadalīšanas un izmaiņu projekta plāns 1928., mērnieks Ed. Laukmanis. LVVA F. 1679., descr. 172., p. 543.

27. LVVA F. 1679., descr. 172., p. 543.

INFORMATION ABOUT AUTHOR:

In 1979 Jānis Zilgalvis graduated from the Faculty of Architecture of the Riga Technical University. In 1990, he defended his doctoral thesis on the subject of the manor architecture of the second half of the $19^{\text {th }}$ century and the early $20^{\text {th }}$ century. Since then, he is the Head of the Architecture Department of the State Inspection for Cultural Heritage. Since 2012 - a full member of the Latvian Academy of Sciences. Over 180 scientific and popular scientific publications and 18 books (some co-authored). The main lines of the research - the manor architecture and cultural history, sacral architecture, protection of cultural heritage.

Kopsavilkums. Par Zasas muižu (Weessen) ir rakstīts l̦oti maz, gan 19. gadsimtā, gan mūsdienās. Lai ieviestu skaidrību šīs muižas īpašniekos, parka veidošanā un īpašuma likteņos tika veikta literatūras un interneta avotu, kā arī arhīvu materiālu izpēte. Objekts vairākkārt apsekots uz vietas. Laika posmā no 1644. līdz 1787. gadam muiža piederēja fon Zasu (von Sass) dzimtai. Vēlāk īpašnieki mainās. Ir zināms, ka 1846. gadā mūžžỉā aizgājis bijušais Talsu (Talsen) apriņ̧̧̧a tiesnesis un Viesienas muižas ķ̄ilu turētājs Vilhelms fon Rummels (von Rummel). Pēcāk muižā saimniekoja, domājams, viņa dēls, arī Vilhelms.

Ap 1865. gadu ieḳīlāto muižu nopirka Vasīlijs Greigs (Greigh). Š̄is dzimtas pirmsākumi meklējami Skotijā. V. Greiga vectēvs bija plaši pazīstamais un slavenais Krievijas flotes admirālis S. Greigs (1735-1788). Viens no S. Greiga dēliem bija Aleksejs Greigs (1775-1845) - jau minētā Zasas muižas īpašnieka Vasīlija Greiga tēvs. Viņš bija ievērojams Krievijas flotes admirālis un viņa krustvecāki bija Katrīna II un grāfs Aleksejs Orlovs. Vasīlija Greiga brālis bija Samuils Greigs, Krievijas armijas ǵenerālis un finanšu ministrs (1878-1880). V. Greigs 1859. gadā bija precējies ar Mariju Kumingu (1837-?) un laulībā dzimuši četri bērni. Vasīlijs Greigs miris 1902. gadā. Muižu mantoja dēls Aleksejs, kurš agrārreformas dokumentos minēts kā pēdējais īpašnieks ar norādi, ka muižas neatsavināmās daḷas tagad pieder Nikolajam Greigam, acīmredzot Alekseja dēlam. Štāba rotmistrs Aleksejs Greigs kā muižas īpašnieks minēts arī Rihtera 
Adresu grāmatā. Agrārreformas rezultātā lielākā daḷa muižas zeme tika sadalīta 88 jaunsaimniecībās. Noteiktas platības tika atstātas un korig̣ētas arī sabiedriskām vajadzībām. Muižas centra saimniecību kopā ar ūdens un tvaika dzirnavām 1924. gadā no muižas īpašnieka I. Stukuls. Pēc viṇa nāves saimniecību mantoja dēls Vilis Stukuls (1909-1996), ievērojams Latvijas zirgkopības speciālists. 1921. gadā muižā atradušās divdesmit piecas dažādas ēkas un būves. Šodien atlikusī muižas centra apbūve grupējas ap taisnstūrveida pagalmu, kura aprises vēl nojaušamas. No senākās kungu mājas saglabājušās tikai drupas. 19. gadsimta otrajā pusē celta jauna kungu māja, kas nodedzināta 1905. gadā. Šī nelielā ēka attāli atgādināja skotu izcelsmes Krievijas arhitekta Ā. Menelasa (A. Menelas, Menelaws, 1747-1831) Krievijas caram Nikolajam I celto kotedžu jeb lauku māju Pēterhofā. Raugoties uz senākās kungu mājas drupām, pa labi redzama neliela koka ēka. Arī tā celta kā Greigu vasaras māja pēc iepriekšējās nodedzināšanas. Šo pagalma malu papildina paliela divstāvu ēka bijusī klēts. Saimnieciskajai apbūvei pieskaitāmas arī ūdensdzirnavas (19. gs.).

Zasas muižas parks ir viena no izkoptākajām un jaukākajām vietām Sēlijā. Tas ir aptuveni 23 hektāru liels un tā veidošana uzsākta jau 18. gadsimtā - baronu fon Zasu laikā un tam ir romantiska ainavu parka iezīmes. Bieži vien dažādās publikācijās minēts, ka tas pēc savas kompozīijas un struktūras atgādina Gatčinas parku pie Pēterburgas. Zasas parku rotā vairāki uzpludināti dīķi, kurus savieno cauri tekošā upīte. Dīķi muižas centra apbūvi ieskauj ielokā. No tiem visos gadalaikos paveras gleznaini skati uz muižas centru, tuvumā esošo baznīcu un dzirnavām. Dīḳos atrodas vairākas saliṇas. Liela uzmanība parka izveidē pievērsta svešzemju koku un krūmu sugām.

Parka ielokā atrodas jau minētā Zasas vidusskola (1939). Parka vienā malā, aiz laukakmeņu mūra žoga paslēpusies t. s. Stukuḷa savrupmāja (1930. gadi). Zasas muižas parks, kā liecina tā izpēte uz vietas, literatūras un arhīvu materiālu apzināšana un analīze ir viens no kultūrvēsturiski nozīmīgākiem ainavu parkiem Latvijas muižās. Tam ir izcilas ainaviskās un dendrologiskās kvalitātes. Parks kopumā saglabājis savu plānojumu un telpisko struktūru līdz mūsu dienām. Nemot vērā minēto, nepieciešams ierosināt Zasas muižas parka iekḷaušanu Valsts aizsargājamo kultūras pieminekḷu sarakstā kā valsts nozīmes pieminekli. 